\title{
Outcrop signatures of relative sea level fall on a siliciclastic shelf: Examples from the Rewa Group of Proterozoic Vindhyan basin
}

\author{
Partha Pratim Chakraborty \\ Department of Applied Geology, Indian School of Mines, Dhanbad 826 004, India. \\ e-mail: partha_geology@yahoo.co.in
}

The Rewa Group of the Vindhyan Supergroup in the Son valley begins with a thick $(\sim 200 \mathrm{~m})$ dominantly shaly, shelfal succession, occurring between the Dhandraul Formation of the Kaimur Group (fluvial sandstone) below and Drammondganj Formation of the Rewa Group (marginal marine sandstone) above. Such a stratigraphic disposition indicates a sharp rise in relative sea level at the onset of Rewa sedimentation, inducing a shelfal depth to the Vindhyan basin. However, a number of wedge-shaped, sandstone/conglomerate bodies (maximum thickness $23.5 \mathrm{~m}$ ) occur at multiple stratigraphic levels within the aforesaid deeper water shale succession, which appear to be of much shallow water origin representing regressive deposits. Though these bodies do not define a single physically continuous unit, either vertically or laterally, they are still designated by a single term 'Asan Sandstone' in the literature. On the other hand, the encasing shelfal shales are termed as Panna and Jhiri Shales, in accordance with their occurrence below or above the so-called 'Asan Sandstone'. The present study reveals that in different sections spread over the Son valley, there are several discrete regressive wedges occurring vertically, and their depositional environment is also variable, ranging between braided fluvial, shoreface fan and braid delta. The features common to most of the regressive coarser clastic bodies are:

- invariable presence of deeper water, shelfal shale below (Panna or Jhiri);

- the underlying shale at places shows signatures of emergence at the top;

- laterally impersistent, wedge-like geometry; and

- presence of granular transgressive lags at the top. These coarser clastic wedges record several episodes of regressive deposition during short-term falling stage or lowstand of relative sea level at the early phase of Rewa sedimentation. Each individual phase of regressive deposition was, however, followed by flooding and resumption of shelf mud deposition.

\section{Introduction}

The Rewa Group constitutes a major portion of the Vindhyan Supergroup in the Son valley (figure 1). Bounded between the fluvial Dhandraul Formation of the Kaimur Group below (Bhattacharyya and Morad 1993) and the coastal Ganurgarh Shale of the Bhander Group above (Chakraborty et al 1998), rocks of the Rewa
Group are exposed all along the synclinal exposure belt of the Vindhyan Supergroup in the Son valley (figure 1). The Rewa Group is entirely siliciclastic, and litho-stratigraphically can be divided into two shelfal argillaceous formations (Panna Shale and Jhiri Shale) and three arenaceous formations (Asan Sandstone, Drammondganj Sandstone and Govindgarh Sandstone) (Chakraborty and Chaudhuri 1990). Whereas Panna Shale, Asan

Keywords. Neoproterozoic; Rewa Group; paleoenvironment; sea level; regression. 

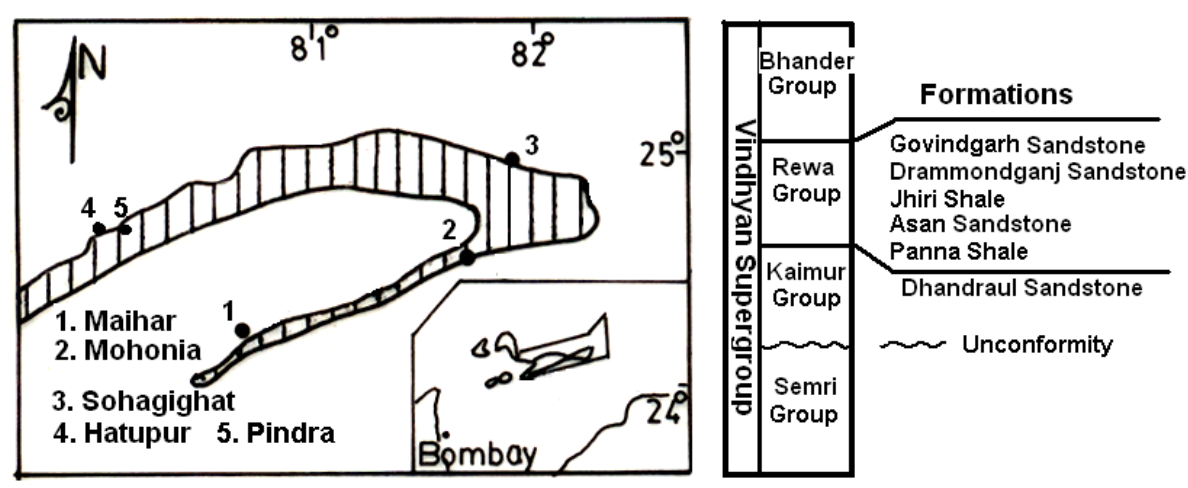

Figure 1. Outcrop map of Rewa Formation showing locations of studied sections. Generalised stratigraphy for the Vindhyan Supergroup is on the right.

Table 1. Facies types of Rewa Shale, their stratification pattern, organic carbon content and inferred depositional environment (after Chakraborty and Sarkar 2005).

\begin{tabular}{|c|c|c|c|}
\hline Facies code & Shale type & Stratification pattern & Depositional environment \\
\hline $\mathrm{A}$ & $\begin{array}{l}\text { Black to greenish black shale } \\
\text { without persistent sandstone } \\
\text { interbeds }\end{array}$ & $\begin{array}{l}\text { Intertwined light and dark sub- } \\
\text { laminae ( } 2-5 \mathrm{~mm} \text { thick }) \text { within } \\
\text { shale, silt interbeds massive; } \\
\text { intervention of well sorted sand } \\
\text { lenticles }\end{array}$ & $\begin{array}{l}\text { Outer shelf beyond storm } \\
\text { wave base }\end{array}$ \\
\hline $\mathrm{B}$ & $\begin{array}{l}\text { Grey shale with HCS bearing } \\
\text { sandstone sheets }\end{array}$ & $\begin{array}{l}\text { Planar laminae topped by } \\
\text { domal HCS }\end{array}$ & $\begin{array}{l}\text { Inner shelf within storm } \\
\text { wave base }\end{array}$ \\
\hline $\mathrm{C}$ & $\begin{array}{l}\text { Reddish brown shale-rippled } \\
\text { sandstone interbedded with } \\
\text { HCS sandstone sheets }\end{array}$ & $\begin{array}{l}\text { Sigmoidal, long toed, low angle } \\
\text { asymmetric ripple laminae; } \\
\text { thicker sandstone units either } \\
\text { channelised or tabular with pla- } \\
\text { nar laminae and cosets of wavy } \\
\text { laminae including HCS }\end{array}$ & Distal shoreface \\
\hline
\end{tabular}

Sandstone and Jhiri Shale in ascending order, constitute the dominantly argillaceous lower part of the Rewa Group, marginal marine Drammondganj Sandstone and fluvial Govindgarh Sandstone together represent its upper arenaceous part (figure 1). Among the sandstone units of the Rewa Group, Asan Sandstone, considered to be sandwiched between Panna and Jhiri Shales, is relatively thin and laterally discontinuous. Bose et al (2001) proposed an informal unit 'Rewa Shale' for the sub-Drammondgunj succession $(\sim 200 \mathrm{~m}$ thick in the Son valley) that includes the intervening sandstone/conglomerate intervals traditionally assigned as 'Asan Sandstone'. The depositional environments of the shales of the 'Rewa Shale' vary from distal shoreface to outer shelf (Bose et al 2001; table 1). Recently, Chakraborty and Sarkar (2005) recognized a number of surfaces within the 'Rewa Shale', at different stratigraphic levels, characterised by emergence features (figures 2 and 3) implying a sharp fall in relative sea level during several phases of 'Rewa Shale' sedimentation. In many areas in the Son valley these surfaces are sharply overlain by coarser clastic units traditionally termed as 'Asan Sandstone'. It thus seems that the formation of these coarser clastic bodies was associated with a fall in relative sea level.

Though the occurrence of sandstone/conglomerate bodies of 'Asan Sandstone' was reported by earlier workers (Chakraborty and Chaudhuri 1990; Chakraborty 1996; Bose et al 2001), a detailed account in terms of process-product relationship, and basin scale variability in depositional motif of these regressive clastic wedges has not been attempted. The present work is based on several such vertically discrete coarser clastic units observed at Hatupur-Pindra, Sohagighat, Mohonia (figures 1, 3, 4). No such unit is present at Drammondganj and Maihar (figure 3). It is argued that none of these coarser clastic units merits assignment of a separate stratigraphic status on a basinal scale because:

- multiple occurrence of these units at different stratigraphic levels without any undoubted criteria are recognizable for their correlation between the sections, and 

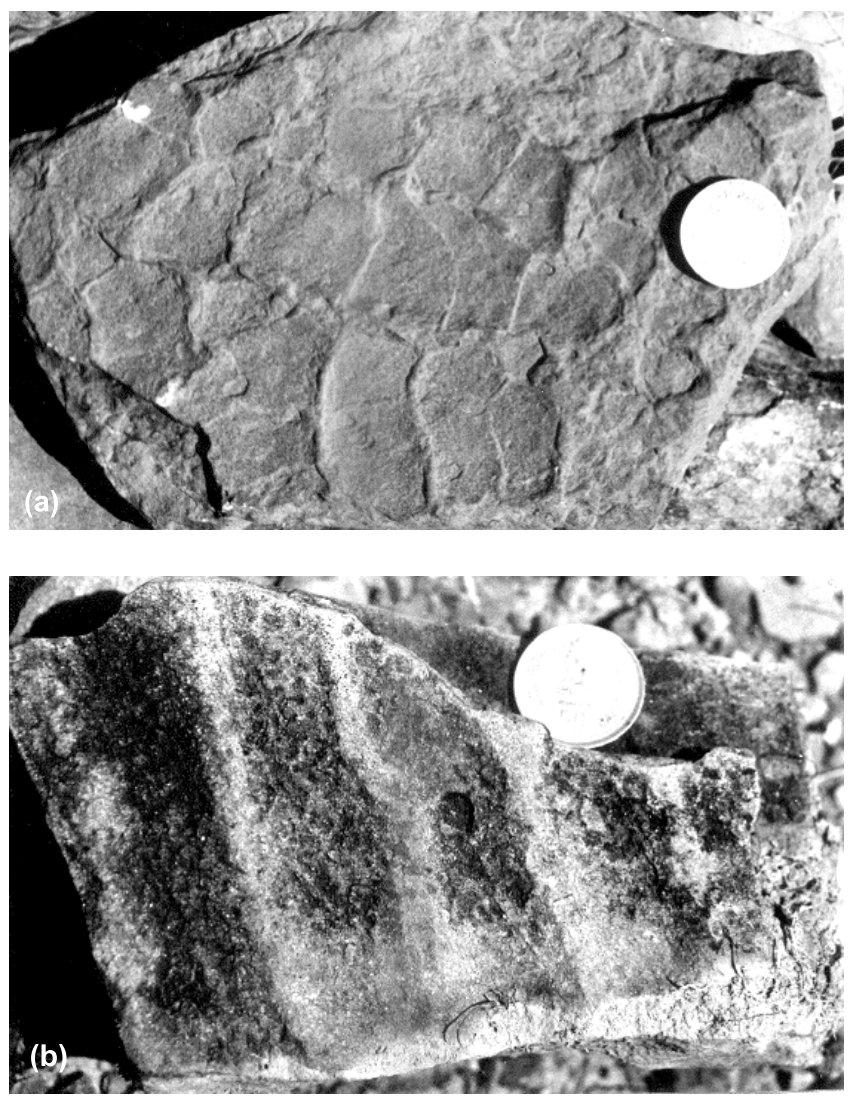

Figure 2. Emergence features viz. (a) mudcrack, (b) rain print on siltstone intervals towards the top of prograding inner shelf Rewa Shale.

- the distinction between Panna Shale and Jhiri Shale on the basis of only colour variation (green and rust brown colour for Panna and Jhiri Shale respectively), as advocated in literature (Pascoe 1975), does not seem appropriate.

Using sequence stratigraphic approach the present study works out the depositional controls for the development of these clastic wedges of 'Asan Sandstone', which are laterally detached and vertically disposed at different levels in the exposed sections spread over the Son valley (figure 1; table 2).

\section{Description of the studied sections}

\subsection{Hatupur-Pindra}

Exposed laterally over a stretch of $8 \mathrm{~km}$ or more around Hatupur village in the northern fringe of arcuate Vindhyan outcrop belt in the Son valley (figure 1), this regressive wedge, constituted of conglomerate, sandstone and shale, is distinct from all other wedges exposed elsewhere (figure 4). Sandwiched between inner shelf and shoreface shale this wedge attains maximum thickness of $23.5 \mathrm{~m}$ and represents a complex association of several paleogeographic and paleogeomorphic components (figure 4). Three major facies associations identified are:

- braided fluvial,

- wave-reworked braid delta, and

- prodelta.

The vertical disposition of facies associations from prodelta deposits at the bottom to the braided fluvial deposits at the top with the wave reworked deposits in between imply a progradational stacking (figure 4; table 2; McPherson et al 1987).

\section{1a Braid plain deposits}

Resting on, and at places incising into, the beach-shoreface sediments (discussed later), the sandstone (litharenite in composition) and conglomerate bodies of this facies association exhibit definite lenticular cross-sectional geometry in bodies up to $0.95 \mathrm{~m}$ thick and tens of meters wide. Most of these units show a simple internal fill with lenticular bodies of conglomerate $(2 \mathrm{~cm}$ to $60 \mathrm{~cm}$ in thickness; having clasts of quartz, sandstone and jasper) present at their base and welldeveloped planar (average coset thickness $50 \mathrm{~cm}$ ) and trough cross-stratified sandstones without any major internal erosion surface forming the rest. Asymmetric curve crested ripples (average wavelength $=7 \mathrm{~cm}$ and amplitude $=0.6 \mathrm{~cm}$ respectively) mantle cosets of planar cross-stratifications in these sandstones.

Presence of conglomerates, poor sorting and thoroughly cross-stratified character for the sandstones and absence of any evidence for wave reworking prompts braided fluvial interpretation for this association. The clast-supported conglomerates at the base of lenticular lithosomes are interpreted as channel lag in origin. The planar cross-stratified sandstones, in contrast, suggest traction deposition within the channels.

\section{1b Wave-reworked braid delta deposit}

The lithosomes of this facies association are comprised of conglomerates and plane laminated and/or cross-stratified sandstones. Like those of braid-delta association, the conglomerates of this association contain pebbles of quartzite, shale, sandstone, volcanics and jasper (max. clast length $15 \mathrm{~cm}$ ) and occasional clastic diamond grains derived from the kimberlite dykes that intruded the underlying Kaimur Group of rocks (Soni et al 1987). The tabular cross-stratified (set thickness $35 \mathrm{~cm}$ ) sandstones are found intertongued with rippled (average set thickness $3.2 \mathrm{~cm}$ ) 


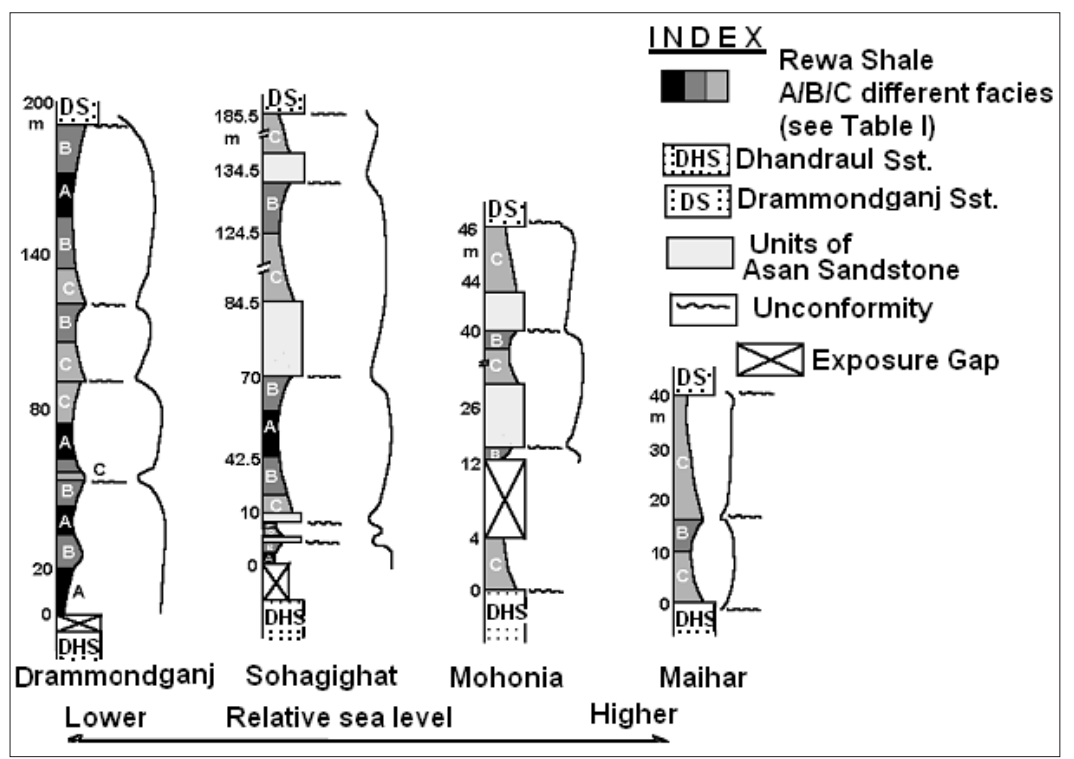

Figure 3. Detailed measured lithologs at different studied sections. Note the presence of coarse siliciclastic wedges at different stratigraphic levels within Rewa Shale succession. The unconformity surfaces at the base of these wedges are associated with emergence features. The alphabets A, B, C indicate different paleogeographic variants of Rewa Shale ( $\mathrm{A}$ = outer shelf, $\mathrm{B}=$ inner shelf and $\mathrm{C}=$ distal shoreface; after Chakraborty and Sarkar 2005). The curve on the right of each litholog represents relative sea level interpreted from the log.

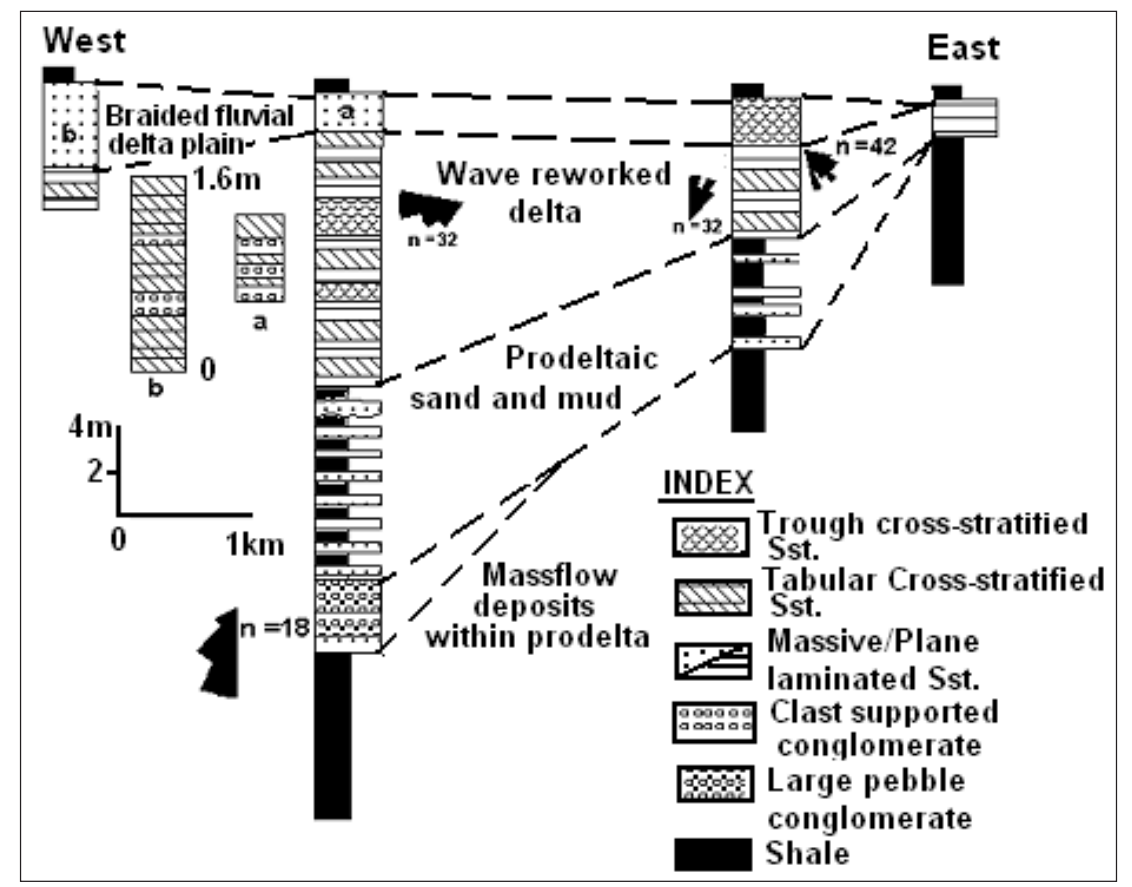

Figure 4. Depositional dip parallel profile in braid delta complex of Hatupur. Products of different depositional systems within the braid delta and associated beach are demarcated and correlated. The internal details within the fluvial delta plain part are shown separately.

cross-stratified sandstones forming decimeter thick units (figure 5), and are interlayered with trough cross-bedded and parallel laminated (with parting lineation) sandstone units. The trough crossbedded units have their bases sharp and tops grading into sandstones having parallel laminations.
The trough cross-sets are, on an average, $12 \mathrm{~cm}$ thick and the cosets make up thickness averaging $70 \mathrm{~cm}$. The basal troughs within the cosets contain a substantial number of oxidized rip-up mud clasts. The paleocurrent direction derived from the troughs point towards west-southwest. 
Table 2. Facies types observed in the Lower Rewa Sandstone.

\begin{tabular}{lll}
\hline Sl. no. & Description & Sections where observed
\end{tabular}

\section{Conglomerate facies}

1. A1. Clast supported (pebble/ boulder) conglomerate, well sorted, ungraded, open framework with lenticular $(1.85 \mathrm{~m}$ wide and $45 \mathrm{~cm}$ thick) bed geometry

A2. Mud pebble conglomerate (av. $20 \mathrm{~cm}$ thick), pebbles are flat, elongated, parallel to bedding plane; occur at the basal part of channel fills

2. B. Boulder conglomerate (av. $18 \mathrm{~cm}$ thick), ungraded with well-rounded clasts of vein quartz, quartzite, jasper, granite, sandstone and rare diamond clasts

3. C. Ungraded, matrix-supported conglomerate with sharp, nonerosive basal contacts; matrix is poorly sorted arenite

Sandstone facies

4. D. Parallel stratified, horizontal, ungraded stratified bands

5. E. Pebbly sandstone with crossbedded planar tabular sets, 0.8 to $1 \mathrm{~m}$ high

6. F. Bouldary to pebbly sandstone, low angle cross-bedding with dips varying along strike

7. G. Trough cross-bedding, av. set thickness $7.5 \mathrm{~cm}$

8. H. Sandstone with

a) small scale planar cross-stratification, av. set thickness $1.75 \mathrm{~cm}$

b) Chevron cross-stratification, av. set thickness $2 \mathrm{~cm}$

Sandstone-Shale alternated facies

9. I. Parallel laminated sandstone alternated with grey/black mudstone, containing wispy silt interlaminae; sandstones with sharp, flat or irregular basal contact
Mohonia, Hatupur

Sohagighat

Hatupur

Mohonia

Sohagighat, Hatupur

Mohonia

Mohonia, Hatupur

Sohagighat, Mohonia

Mohonia, Sohagighat, Hatupur

Mohonia

Mohonia

Intermittent tractive currents transporting sand on a muddy substrate, associated with alternating high and low flow conditions, perhaps tidal or storm currents
Bedload deposition from high velocity flows preventing deposition of finer sandy materials, suggestive of channel lag

Channel lag, clasts derived from reworking of underlying muddy substrate

Boulder lags from hyperconcentrated flood flows or megaflood flow boulder beds

High concentration flow dispersion or hypoconcentrated flood flow dispersions, clast support from dispersive pressure

Upper flow regime tractive transport of sand grains

Bedload deposition on slipface of linear crested dunes or small bar foresets during high velocity flows

Traction flows with deposition in broad, shallow scour fills

Traction current deposition from sinuous-crested dune bedforms

Lower flow regime conditions, deposited from linear crested ripple/ dune bedforms

Lower flow regime condition, dominance of oscillatory flow
Westward, this facies association is cut into by the conglomeratic braid-plain sediments while on the east, sediments of this association are found resting directly on to the offshore Rewa Shale onlapping the shelf sand-mud successions (near the village Birshapur, $2.5 \mathrm{~km}$ eastward of Hatupur).

The inter-tongued tabular cross-stratified and asymmetric wave-cum-current rippled sandstone units are interpreted as a product of ridge-runnel system in a beach environment. This interpretation is supported by the observation of exhumed ridgerunnel system on bedding plane exposure of beach sediments (figure 5). The sharp, erosional based trough cross-bedded units are interpreted as products of channels in shallow subtidal/shoreface setting. Presence of the parallel laminated sandstone units imply the establishment of beach conditions (Bose and Chakraborty 1994). The establishment of a beach-shoreface environment bears evidence of wave reworking on the delta. 


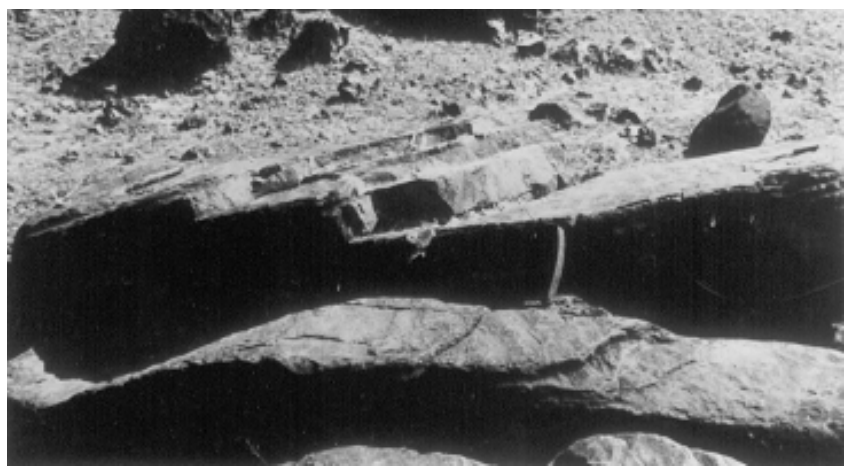

Figure 5. Beach ridge cross-strata in wave reworked braid delta complex of Hatupur (hammer length $27 \mathrm{~cm}$ ).

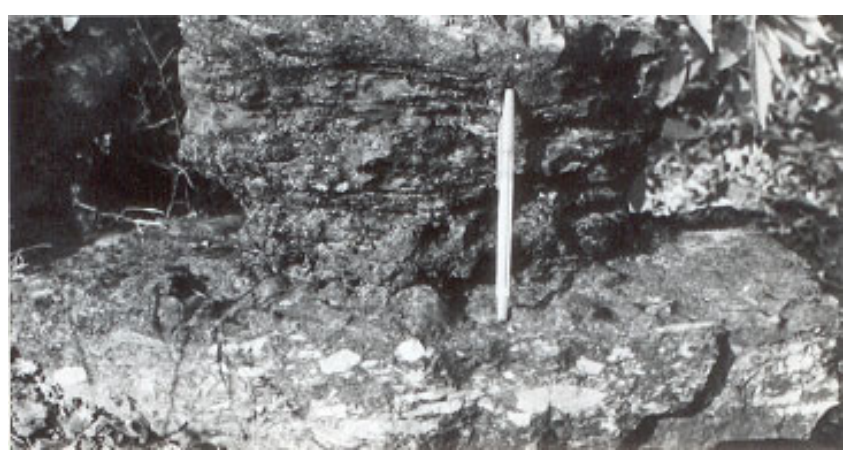

Figure 6. Conglomerate overlain by stratified sandstone in the detached massflows of Hatupur (pen length $14 \mathrm{~cm}$ ).

\section{1c Prodeltaic mudstone}

An $\sim 8 \mathrm{~m}$ thick succession of sandstone-silty mudstone alteration is exposed towards the basal part of Hatupur-Pindra section near the village Birshapur. The shale interbeds are plane laminated and incorporate stringers (av. thickness $\sim 0.8 \mathrm{~cm}$ ) of sand. The sheet sandstone interbeds, with sharp, planar base and sharp to gradational top, are internally massive and/or plane laminated and occasionally weakly graded. The structural sequence within the sandstone interbeds resemble truncated $\mathrm{T}_{\mathrm{ae}}$ or $\mathrm{T}_{\mathrm{abe}}$ successions of Bouma (1962). Up the succession thickness of sand interbeds increases regularly (from 0.4 to $1.2 \mathrm{~cm}$ ) along with increase in grain size. The topmost sand body, however, is contrastingly thick $(\sim 90 \mathrm{~cm})$ within the entire succession and is characterized by the presence of overlapping small channels with average width:depth ratio of 2.5 and massive internally.

The sheet sandstone interbeds with Bouma divisions can be attributed to turbidite deposition from light density flows or buoyant plumes in a mud depositional environment. The thin, laterally extensive nature and relatively low volume of sand are suggestive of distal depositional setup. Lack of signatures of wave reworking indicates that the depositional environment was below storm wave base. Distinction between products of shelf and prodelta environments is difficult in Proterozoic successions in the absence of deep burrowing infauna (Bhattacharya and Walker 1992). However, based on its association with braided fluvial and wave reworked shallow marine deposits, a prodelta to distal shelf paleogeography is proposed for this unit. The upward increase in thickness and grain size of sandstone interbeds and occurrence of overlapping channels at the topmost sandstone interval of this association suggest progradation within the prodelta up to the delta front domain.

Associated with the prodeltaic deposits, a lenticular unit constituted of large pebble (av. clast size $3.8 \mathrm{~cm}$ ) conglomerates (matrix- and clastsupported), sandstone and shale is observed in the basal part of one of the studied sections (figure 4). The conglomerate units are internally massive, at places, normally graded and with rarely present southerly-directed cross-stratifications. The bed thickness of these conglomerate units varies between 55 and $70 \mathrm{~cm}$. In some matrix-supported variety, pebbles are disorderly arranged and protrude the upper bed surfaces. The sandstones are massive or stratified and have lenticular or tabular geometry. Some massive/plane laminated sandstone bodies superjacent to the conglomerate bodies (figure 6) have indistinct boundaries seemingly due to infiltration of sand between the protruding pebbles of the underlying beds.

The normally graded pebble beds with lenticular geometry bear testimony to detached mass flow and in particular, modified grain flow (cf. Middleton and Hampton 1973), because the pebbles cannot be transported in suspension by turbulence alone (Pantin 1979; Lowe 1982). Deposition must have taken place under water, because in subaerial conditions dispersive pressure is likely to get dissipated readily. The sandstones with rarely present cross-stratification, however, indicate traction deposition. The eastward wedging of this fan system (figure 4) is suggestive of bypassing of sea margin.

\subsection{Sohagighat}

\section{2a Braided fluvial system}

Encased within the shale of the Rewa Group four (2 to $15 \mathrm{~m}$ thick) multistoried sandstone/conglomerate units are exposed in the Sohagighat section (figure 7). In the exposure scale each of these coarse clastic units is lenticular in geometry (max. recorded exposure length $2.6 \mathrm{~m}$ ) with concave-up, erosional base (figure 8). Above the emergent inner shelf shale individual storey commences with a distinctive basal conglomerate enriched in oxidized rip-up mud pebbles. 


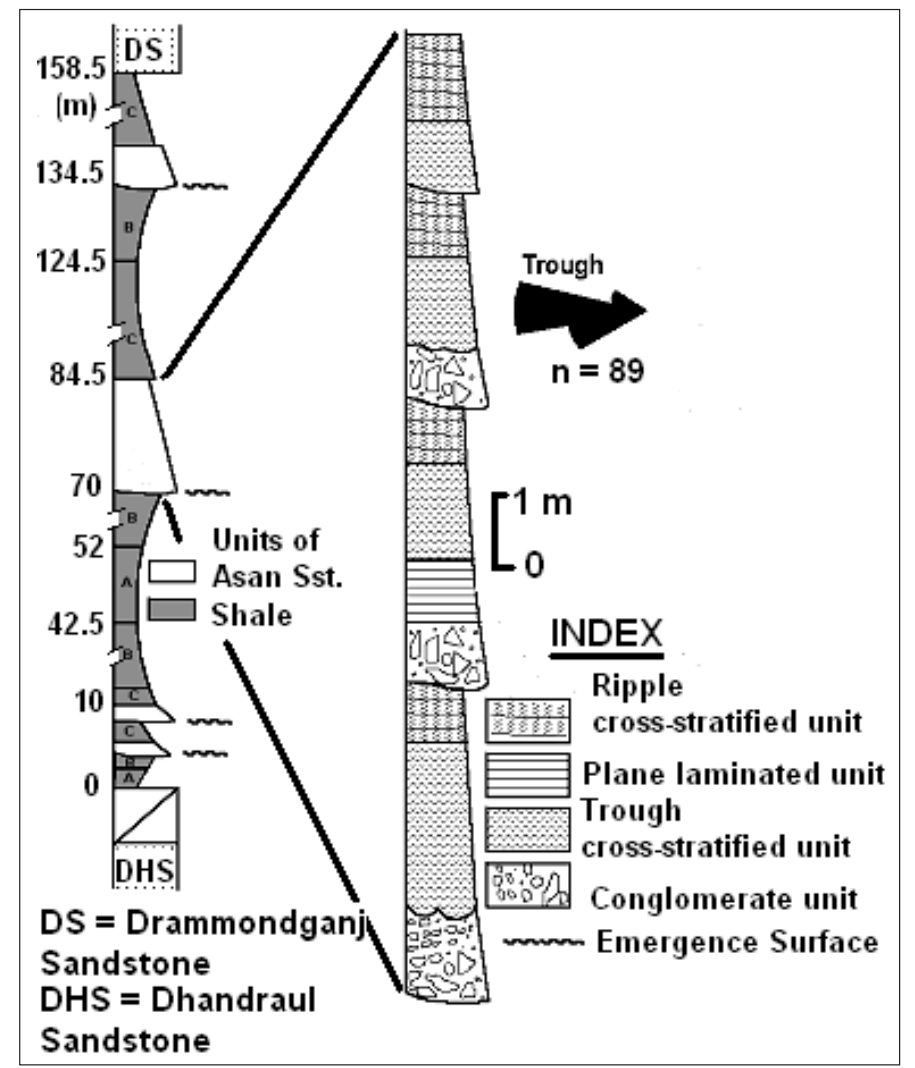

Figure 7. Measured litholog of Sohagighat section. Fining up character of individual storey within multistoried fluvial succession is shown on the right. Paleocurrents measured from channel-fill trough cross-stratifications is shown alongwith.

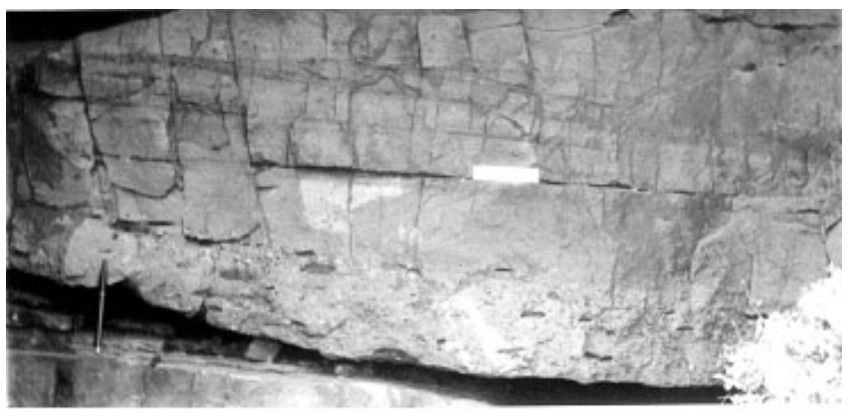

Figure 8. Channelised fluvial unit with shale pebble conglomerate at the base overlain by plane laminated sandstone (pen length $14 \mathrm{~cm}$ ).

Upwards within a storey the conglomerate gradually becomes cleaner, finer and better sorted. Plane laminated division (average thickness $30 \mathrm{~cm}$ ) followed by cosets of trough cross-stratification is common structural sequence in poorly sorted quartz arenites, which overlie the conglomerates in the upper part of each storey. Keeping the set thickness nearly uniform (varying between 4 and $6 \mathrm{~cm}$ ) the trough cross-stratifications show a definite tendency of decrease in co-set thickness up a storey. The trough cross-stratification azimuth, taking data from all the four units together, is unimodal and directed westward (figure 7). At places, rippled division of average thickness $4 \mathrm{~cm}$ mantle the storey. The ripples (av. wave length and amplitude $4 \mathrm{~cm}$ and $0.6 \mathrm{~cm}$ respectively) are asymmetric in profile and cuspate in plan. Paleocurrent direction measured from all ripple-laminated units at Sohagighat section show a broadly westward migration.

Several storeyes, each constituted of basal conglomerate and sandstones with plane lamination, trough coset and ripple laminated division, are stacked to build up multistoreyed sandy/conglomeratic units. Individual storeyes reveal perceptible fall in grain size from bottom upwards. Besides, overall fining and thinning up trend is also apparent within the multistoried unit despite the fact that grain size in the basal part of any individual storey is distinctly larger than the grain size in the topmost interval of its immediately underlying storey (figure 7).

Each of these multistoreyed units is mantled by a clean (mud free) granule sheet (of average thickness $2.5 \mathrm{~cm}$ ) before being overlain by outer shoreface shale. Under microscope a distinct bimodality in grain size $(0.08$ and $0.9 \mathrm{~mm})$ is apparent in these granule layers. Monocrystalline quartz grains, siltstone and sandstone clasts are found 


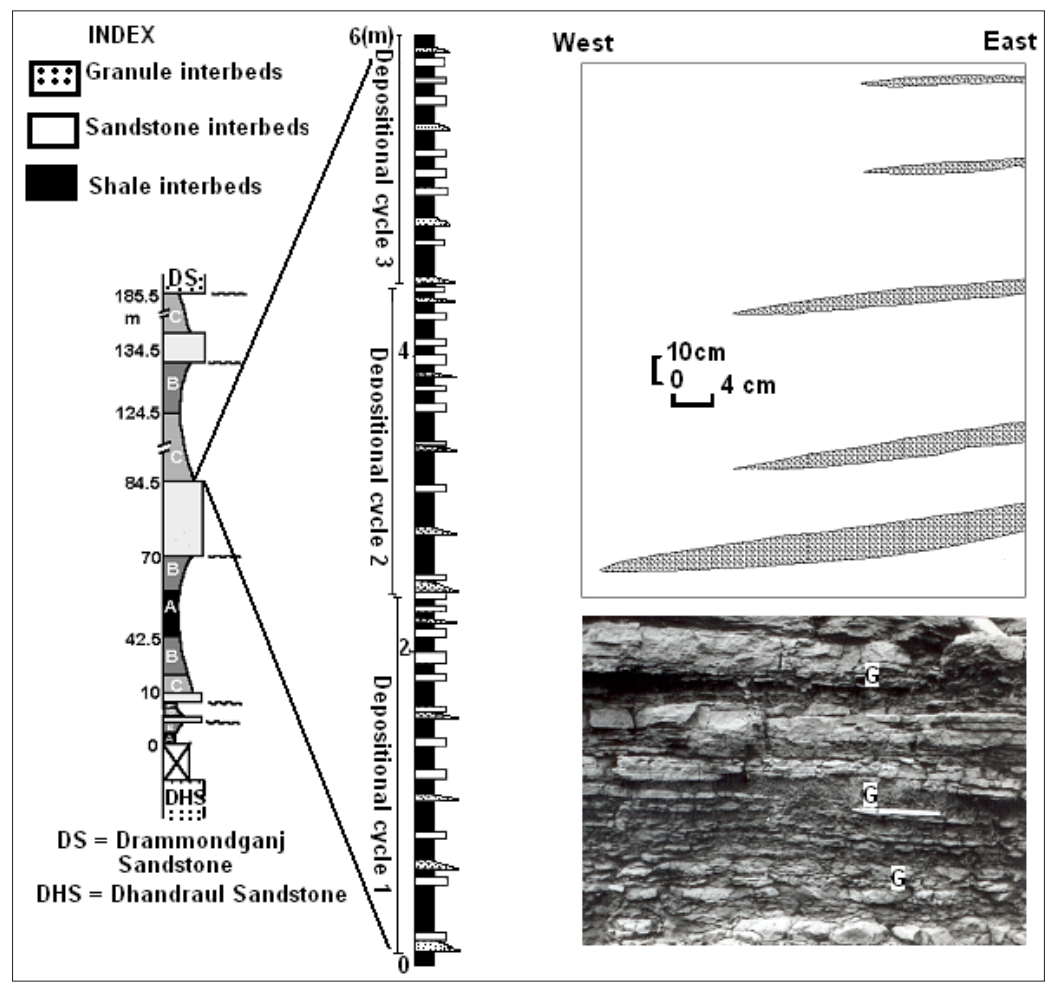

Figure 9. Detailed measured litholog for the transgressive lag of Sohagighat section. Note upward thinning-up character of granule layers defining depositional cycles. Photograph on right top shows the granule $(\mathrm{g}$ ) layers (pen length $14 \mathrm{~cm})$. Figure on right bottom $(\mathrm{C})$ is the field sketch demonstrating westward pinching character for the granule layers.

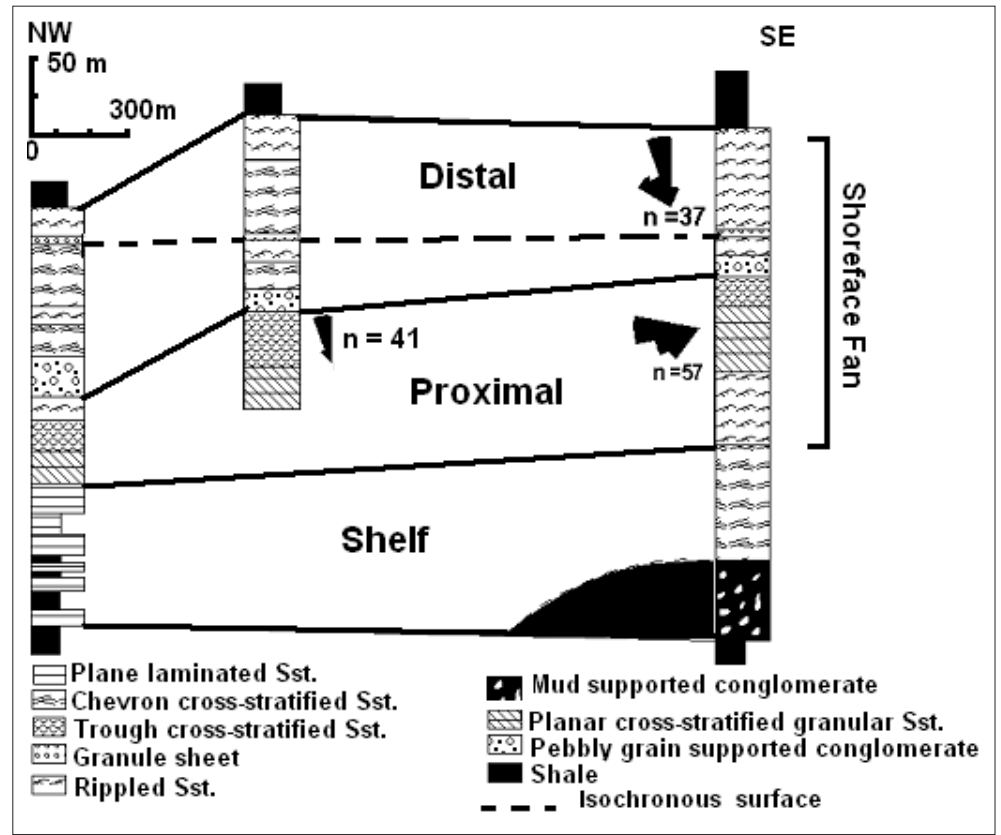

Figure 10. Facies distribution in three sections of the shoreface fan. The solid lines joining the three sections represent the isochronous reference planes. Distribution of marine and terrestrial bodies has been delineated. Note: i) lobate character for mud supported conglomerate ii) westwardward overall thinning of the fan and iii) general eastward thinning of the marine bodies.

floating within patchy silty and sandy groundmass. Many of the lithic clasts are deformed and evidently squeezed between other adjacent grains. Occasionally, the granule sheets are found moulded in the form of wave ripples (av. wave length $=2.3 \mathrm{~cm}$, amplitude $=0.6 \mathrm{~cm}$ ). 
Sharp, concave up erosional base, presence of channel lags dominated by rip-up clasts, overall fining and thinning up character within multistoreyed bodies, clear evidence of decline in flow strength upward within individual storey (from conglomerate to rippled sandstone division) collectively favour fluvial channel origin for these clastic bodies (Collinson 1996; Eriksson et al 1998). Unimodal paleocurrent and association of abundant emergent features in the shale immediately underlying these clastic units also confirm this contention. The individual fining-up storey depicting declining flow regime resembles individual channel fills (Bose and Chakraborty 1994).

\section{2b Transgressive lag deposits}

Overlying the fluvial package, a multistoreyed sequence ( $8 \mathrm{~m}$ in thickness) can be observed in the Sohagighat section. The succession is constituted of grey shale, granule and fine-grained parallelsided sandstone beds, in recurrent alterations (figure 9a, c).

The granule beds (max. thickness $12 \mathrm{~cm}$ ), having sharp and erosional bases, are massive, more or less well-sorted and rich in volcanic, sedimentary as well as, sparingly present metamorphic rock fragments. The granules are highly oxidized, some showing pisoidal concentric rims. The intergranular spaces are filled with very fine sand and mud matrix (5-10\% in volume). Encased within shale most of the granule beds occur in isolation, a few are followed up by parallel-sided sandstone. The noteworthy feature in these granule beds is their wedge-shaped geometry (in tens of meter scale) with rapid pinch-out towards west (figure 9b).

The associated sandstone beds are either massive or plane laminated except for the topmost part of this facies association. The straight crested wave ripples present at the topmost part have amplitude and wave length, on average, $0.7 \mathrm{~cm}$ and $8 \mathrm{~cm}$ respectively. Being commonly asymmetric in profile, these ripples show dominant migration towards east-northeast.

Better preservation of this lithic assemblage in an $\sim 6 \mathrm{~m}$ thick section allowed its detailed observation and revealed the presence of three short (max. thickness $2.46 \mathrm{~m}$ ) depositional cycles, each defined by upward decrease in thickness of the granule beds (figure 9a). Within every cycle the sandstone bed frequency increases upwards and the set of cycles, as a whole, becomes relatively sandier at the expense of the granule beds. Towards the top of the section ripples of combined flow origin mantle sets of sandstone beds.

Alternation with retrograding shoreface succession, the solitary (unamalgamated) occurrence and sharp erosional bases for the massive granule bodies possibly point to their origin by the process of ravinement (Cattaneo and Steel 2003). The ravinement eroded the underlying fluvial deposits and dispersed the eroded sediments in the form of granule layers. As regards to the sandstone beds, neither do they reflect any systematic change in bed-thickness nor do the granule beds generally succeed them. An independent depositional mechanism for the sands is invoked. In view of regular alteration and invariable sharp contact with the encasing shale interbeds, an episodic high-energy depositional mechanism, such as storm has been surmised for the sandstone beds.

The systematic change in thickness of the granule beds in all the three cycles is suggestive of gradual filling of available accommodation space. An aggradation is implied. The recurrent presence of such cycles indicates punctuated transgression, with alternating retrogradation and aggradation within an overall transgressive trend (Cattaneo and Steel 2003). The accommodation space generated by intermittent rise in relative sea level is eliminated during the interludes through deposition of sediments delivered from the source towards east.

\subsection{Mohonia}

\section{3a Shoreface fan}

Two coarse clastic units (figure 3) represent this depositional system at Mohonia section and demonstrate paleogeographic variation ranging between terrestrial and marine. Quartz (>90\%) and a minor but significant amount of volcanic rock fragments $(2 \%$ to $5 \%)$ constitute rocks of these units. Two complete and one bottom-truncated vertical lihologs spanning over a two km long NESW stretch (figure 10) allowed documentation of facies types and facies associations. Overlying the shelf sediments (represented in the basal part of the profile), the deposits of this fan system are found with retrogradational stacking with the distal fan products overlying the proximal fan deposits.

\section{3b Shelf association}

Representing the basal of the profile, the mud supported conglomerate, heterolithic sandstone-shale and chevron cross-stratified sandstone constitutes this facies association. While occurrence of mud supported conglomerate (Facies A2; table 2) is noted only in the easternmost section, the lone occurrence of alternated sandstone-shale (Facies I) can be observed in the westernmost section. Within the exposure constraint the mud-supported conglomerates show convex up lobate bed geometry (max. thickness measured $1.5 \mathrm{~m}$ ) and reveal clasts 


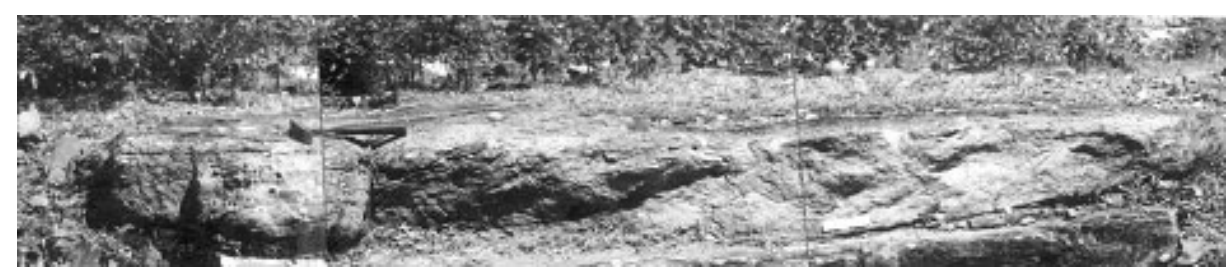

Figure 11. Channelform planar cross-stratified granular sandstone in shoreface fan of Mohonia (hammer length $27 \mathrm{~cm}$ ).

(max. clast length $7.5 \mathrm{~cm}$ ) in disorganized fashion. Towards northwest in the heterolithic sandstoneshale facies the upward increase in amalgamation of the sandstone intervals bears signature of progradational stacking. The chevron crossstratified sandstones (Facies H2) are noted only in the section towards southeast.

The plane-laminated sandstones in alternation with grey shale in the northwestern section are interpreted as a product of occasional high-energy storm on a relatively sediment-starved landward margin of inner shelf (cf. Siringan and Anderson 1994). The chevron cross-stratified sandstones, interpreted as a product of wave agitated shoreface or proximal inner shelf, are best developed in the southeastern part indicating persistence of favourable paleogeographic situation for a longer span of time. The lobate geometry and occurrence of randomly oriented clasts are suggestive of debris flow origin for the mud-supported conglomerates (Dickie and Hein 1995; Boggs 1995).

\section{3c Proximal fan association}

Planar cross-stratified granular sandstone, trough cross-stratified sandstone and rippled sandstone constitute this facies association. Units with coset (av. thickness $28.5 \mathrm{~cm}$ ) of planar cross-stratifications have their bases concave-up (figure 11) and reveal fining-up character with accompanying decrease in cross-set thickness. The paleocurrent measured from these crossstratifications is unimodal and points towards west southwest. The relatively better sorted sandstones with coset/s (av. thickness $15 \mathrm{~cm}$ ) of trough crossstratification overlie the granular planar crossstratified sandstones and represent northward paleocurrent (figure 10). The thin $(\sim 4 \mathrm{~cm})$ wave rippled sandstones that mantle the trough crossstratified sandstones define the topmost interval for the entire lithopackage. Similar to the trough cross-stratifications the ripples also show their migration towards north-northwest.

The concave-up base and fining-up character of planar cross-stratified granular sandstone units suggest deposition as channel fills in a nearshore position related to a fluvial or a tidal system
(Shanmugam et al 2000). The better-sorted sandstones with trough and ripple cross-stratifications and with paleocurrent direction nearly at right angle to that obtained from the planar crossstratified sandstones, are interpreted as possible ravinement (Kidwell 1991) deposit generated by reworking of preexisting shoreline products.

\section{3d Distal fan association}

Towards the top part of the lithopackage, this facies association is constituted of three different facies types viz. pebbly grain-supported conglomerate, rippled sandstone and chevron crossstratified sandstone. Together with sandstones the conglomerate units display beds with concave-up channel geometry and best developed in the basal part of this association. Internally the conglomerate units exhibit a clear bipartite division: the lower part is massive, pebble-supported (with sand grains occupying only the intergranular space) and the upper part, although thin, is fine grained with pebbles sparsely floating within sandy matrix; the contact between the two parts is highly irregular and diffused. The chevron cross-stratified sandstones (Facies H2) are unequivocal in its presence towards the upper part of this association in all the three studied sections. A granule layer containing clasts of sandstone and vein quartz is noticed intervening this facies association in all the three studied sections.

A channelised massflow with two-phase flow transformation, i.e., transformation from grain flow to debris flow through rapid injection of water in moving mass of sediment (Fisher 1983) is interpreted for the conglomerate units present in the basal part of this association. The chevron cross stratified and ripple cross stratified sandstones in the upper part of this association bear undoubted signature for dominance of marine processes, e.g., wave in the upper part. The granule layer, containing clasts derived from underlying sandstones and intervening the facies association in its upper part, is interpreted as product of transgressive lag. Formation of such inter-facies lag deposits possibly suggests intermittent increase in the rate of relative sea level rise in an overall transgressive mode and 
thereby causing flooding and ravinement (Abbott and Swett 2000).

Reconstruction of depositional architecture in shale encased coarse clastic bodies heavily depends on identification of isochronous surfaces and tracing them in space. Both upper and lower contacts of this clastic unit with the encasing shale serve the purpose for the present work. Besides, the base of the grain supported pebbly conglomerate was also taken as another isochronous surface considering its instantaneous emplacement motif. The granule layer, inferred as transgressive lag (figure 10), offers another isochronous surface for correlation. Adjusting the sections with respect to these surfaces, westward wedging for the fan became apparent. The thickest development of the wedge, confinement of basal conglomerate and dominance of shallow pebble rich channels indicate that the eastern part of the wedge represents the proximal or landward part of the fan. Frequent wave imprints in the western part and dominance of shallow channels in the easternmost section also suggest that the sea was on the west. The wedge-like shape, initial lobate massflow deposits in the proximal part and two-phase evolution of another massflow at a subsequent stage strongly suggest that this clastic wedge developed at the lee of a slope break. Abundance of fair weather wave features suggests that the slope break was in the shallow domain, possibly between waveagitated shoreface and seaward mudline. Development of such a slope break on a supposedly flat muddy shelf can only be plausible through differential subsidence triggered through basin margin tilting.

\section{Depositional controls}

The process based facies and facies succession analyses over $1200 \mathrm{~km}^{2}$ area allowed Chakraborty and Sarkar (2005) to document depositional cyclicities in various orders and to identify surfaces of emergence at discrete stratigraphic levels within Rewa Shale, coinciding with third-order depositional cycles for which they assigned the status of 'depositional sequence'. Being confined within the distal mud dominated succession, signatures of these emergent surfaces though cryptic yet subtle and can not go unnoticed. Each such subaerial discontinuity invariably coincides with sharp paleogeographic shift from inner shelf to shoreface and marked by features like sand-filled polygonal cracks, runzel marks, rain prints, rain-induced ripples and salt pseudomorphs (figure 2).

Expecting insignificant bathymetric changes in subtidal settings of epeiric basins against any sea level variation (cf. Sarkar et al 2002), the present search was principally concentrated along coastal parts of Rewa basin, where expressions of unconformities should have been most pronounced. Exposure limitation did not allow physical tracing of emergent surfaces from proximal to the distal part of the Rewa Shale basin. Despite this, the very occurrence of regressive wedges (particularly those related to the 'falling stage' braid-delta system; discussed later) above progradational and emergent inner shelf shale at different stratigraphic levels prompted the author to interpret these wedges representing depositional systems on the Rewa coastline coeval to the episodes of emergence independently recorded from the mud dominated counterparts. Basinally, the features common to all regressive units are:

- their invariable presence above inner shelf (above storm wave base) shale and being overlain by sandstone-silty shale of shoreface origin

- laterally impersistent and wedge shaped geometry

- sharp basal contact with the inner shelf shale, commonly demarcated by erosional conglomeratic lag

- presence of granular sheet of transgressive origin on their upper contact

- common association with emergence features

- presence (5-25\%) of extraneous rock fragments, otherwise uncommon in the entire Rewa Formation, within the basal erosional lag and

- domination of volcanics in the lithic extraclast population. Recurrent falls of relative sea level are indicated through the Rewa Shale sedimentation history.

Between the studied sections the widely varying physical and paleogeographic character of the wedges, however, reflect that the local factors also imparted major forcings on the deposition of these wedges. While the dominantly conglomeratic braid delta of Hatupur and shoreface fan of Mohonia suggest availability of relatively steep depositional slope, the essentially sandy, at best granular fluvial system of Sohagighat indicate a much gentler depositional gradient (discussed later). Paleocurrent patterns identified from the regressive units at different sections also differ widely indicating the importance of local forcings. At the Sohagighat section, the westerly/northwesterly paleocurrent shown by different directional elements in the fluvial association and the westward wedging for the granule layers of the transgressive lag are well consistent and indicative of supply on the regressive shelf from east/southeast. This view is also supported by the westward paleocurrent obtained from channel products in terrestrial/marginal marine association of the shoreface fan at Mohonia. Such consistent paleocurrent towards west as displayed 
by the channel products irrespective of their paleogeographic settings is possibly the reflection of broad westward slope at least in the eastern part of the Rewa Shale basin. A north-south paleoshoreline orientation for the Rewa Shale basin is inferred for this part, which gets support from the orientation of crest lines of wave ripples present in the shoreface fan section. In contrast, southerly paleocurrent shown by the cross-stratified sandstones associated with the detached massflows in the braid-delta section of Hatupur, on the northern margin towards west of the exposure belt, suggests possible supply also from the north, at least in the northwestern margin of the Rewa Shale basin. The trough cross-stratifications showing westward paleocurrent in beach-shoreface setting are possibly product of shore parallel current operative on subtidal/shoreface setting within the braid delta.

Though assessing time-equivalence between these regressive wedges is beyond the scope of present work in absence of subsurface data, it is believed that depending on rate of sea level fall, local physiography and character of supplied sediment, regressive wedges developed at different sections with widely varying number and genetic character.

\subsection{Physiography and sediment supply}

Chakraborty (1994) invoked braid plain progradation for the topmost sandstone interval (Dhandraul Quartzite Formation) of the Kaimur Formation. Considering such long progradation in late Kaimur history to be valid, a reasonable reconstruction of the Rewa shelf basin configuration at the end of Kaimur Formation deposition has been made by plotting the vertical distance of the top of Dhandraul Quartzite down from the contact between Rewa Shale and Upper Rewa Sandstone (figure 1). In the absence of any basin scale evidence indicating significant erosion following the deposition of Rewa Shale, its thickness variation over the entire study area is interpreted as result of differential subsidence prior to or concomitant with Rewa sedimentation (Chakraborty 1996).

Physiographic variation resulting out of such spatially inconsistent subsidence can have a major impact on the amount of shoreline migration associated with any relative sea level change. In the Sohagighat section, occasional presence of oxidized mud pebbles within the channel lags of some regressive fluvial bodies without any input of extraclasts possibly suggest moderate gradient of the shelf that allowed only cannibalization of the exposed shelf through channel incision resulting rip-up clast generation, but did not permit large scale import of clasts from extraneous sources.
The large and extraneous pebble rich braid delta at Hatupur, on the other hand, indicated exposure of a considerably steeper slope. The current structures in the sandstones genetically related with massflows indicate a southward slope. A tectonic forcing is suggested by the episodic coarse-grained massflows, carrying extraneous clasts. Despite frequent presence of these massflows abundant association of large-scale cross-bedded sandstones and local lateral transitions to the beach facies reflect nearshore paleogeography. Sudden input of very coarse clastics on to the shelf implies considerable tilting of the basin margin. Considerable uplifting of the source area is also attested by incorporation of diamond and kimberlite fragments derived from the underlying Kaimur Formation.

\subsection{Falling stage versus lowstand}

Shallow marine deposits with rapid offlapping and progradational stacking character and showing age-equivalence with deep marine submarine fans are considered as ideal candidates for forced regressive deposition (Hunt and Tucker 1992; Catuneanu 2002). The prograding braid delta (with beach and shoreface) succession of Hatupur is interpreted as product of 'falling stage' of sea level because of its

- sharp, erosional base,

- presence immediately above shoaling-upward highstand inner shelf shale and

- overlying retrogradationally stacked distal shoreface shale of possible late lowstand or early transgressive origin.

In contrast, the fluvial and shoreface fan bodies, with sharp/gradational base and retrogradational stacking motif, resting either directly on unconformity surface or interbedded with the deepening-up shoreface succession, prompted the author to interpret as product of low stand with slow rise in relative sea level.

\section{Discussion}

Encased at multiple stratigraphic levels within offshore Rewa Shale, the coarser siliciclastic wedges of Lower Rewa Sandstone, representing widely variable depositional environment and grain size, bear undoubted signatures for several episodes of relative sea level fall induced either by eustacy and/or tectonism. While signatures of emergence within the shale immediately underlying (in case of lowstand) or overlying (in case of falling stage products) these wedges bear telltale evidence in favour of exposure of the depositional substrate and unconformity formation, basinward tracing of their coeval planes can be done through the 
recognition of thin $(<2 \mathrm{~cm})$ laterally impersistent reddish coloured poorly sorted granular sandstone layers right at the transition between inner shelf and shoreface products. Accepting the spatially uneven physiography for the Rewa basin floor (following the Kaimur sedimentation; figure 1), it can be surmised that spatially variable basin physiography, the amount and type of sediment availability at different areas and locally important basin margin tilting possibly led the observed variations in Lower Rewa wedges in response to large-scale regressions on the Rewa Shale shelf.

The appreciable difference in preserved thickness of regressive bodies at different sections further indicate availability of spatially variable accommodation space on the regressive shelf depending on local physiography. Braid delta and shoreface fan developed where supply of coarse-grained sediment was high and basin floor gradients were steep. Effect of basin floor tilting in generation of increased basin margin slope on an otherwise low gradient epeiric shelf is apparent in presence of massflows and high percentage of extraclasts in these regressive bodies. This conjecture of tectonic perturbance in the Hatupur region preceding the formation of the braid delta is also confirmed in abundantly present synsedimentary faults and evidences of hot pyroclastic flow in the nearby regions Majhgawan and Pindra respectively (Chakraborty et al 1996). In the Mohonia section, the paleogeographic variation in shoreface fan system, however, suggests relatively short sea level change, varying between mid-shelf and wave-agitated shoreface.

In contrast, limited supply of coarse-grained sediment and low gradient of the basin floor at Sohagighat allowed only cannibalization of the exposed shelf by encroaching fluvial system, without significant supply of extraclasts. The channel lag, if present in this fluvial system, is dominated by oxidized mud pebbles ripped up solely from the exposed shelf. The very low gradient of the exposed shelf could have permitted only a minimal channel incision and the river encroaching upon it could have anastomosed. The fining-up character of single fluvial storey and fining- and thinning-up character of the entire fluvial system in Sohagighat section bear the signal for individual channel fill and filling of entire fluvial valley created by channel incision associated with unconformity development. An on-shelf fluvial succession, without accompaniment of a time equivalent slope fan implies relatively shorter fall in relative sea level, not exposing the shelf edge. In this backdrop, the occurrence of stepped channel in topmost fluvial body at Sohagighat indicates scouring of a slope shoulder that extended landward with continued erosion. The wave rippled granular lag surface that mantle the fluvial succession is interpreted as of ravinement origin (Galloway 2001).

\section{Conclusions}

Detailed basin-scale observations within Asan Sandstone Member, Vindhyan Supergroup allowed identification of a number of regressive wedges at multiple stratigraphic intervals associated with episodes of emergence and unconformity development those punctuate the Rewa Shale depositional history. Between different sections the wedges vary in number and their genetic character. Process based facies analysis and detailed documentation of facies succession through litholog measurement revealed establishment of widely variable paleogeographic settings within these regressive wedges viz. braid delta, shoreface fan and fluvial related to falling stage or lowstand of sea level at different parts of Rewa Shale shelf. While braid delta (Hatupur section) system is identified as product of falling stage of sea level, the shoreface fan (Mohonia section) and fluvial systems at Sohagighat are formed at lowstand that witnessed early slow rise in relative sea level. Spatially variable basin physiography, the amount and type of sediment availability and locally important basin margin tilting possibly led the observed variations in Lower Rewa wedges. Correlation between these wedges in absence of subsurface data could not be possible, since these wedges cannot be traced between isolated sections.

\section{Acknowledgements}

The author is thankful to the Department of Science and Technology (DST) and the Council for Scientific and Industrial Research (CSIR) for financial help. Department of Applied Geology, Indian School of Mines provided the necessary infrastructural facilities. Thanks are also due to two anonymous reviewers for their suggestions that improved the earlier version of this manuscript.

\section{References}

Abbott S T and Sweet I P 2000 Tectonic control on third-order sequences in a siliciclastic ramp-style basin: an example from the Roper Superbasin (Mesoproterozoic), northern Australia; Australian J. Earth Sci. 47 637-657.

Banerjee I 1974 Barrier coastline sedimentation model and the Vindhyan example; Quart. J. Geol. Min. Met. Soc. India (Golden Jubilee vol.) 46 101-127.

Bhattacharya A and Morad S 1993 Proterozoic braided ephemeral fluvial deposits: an example from the Dhandraul Sandstone Formation of the Kaimur Group, Son Valley, central India; Sedim. Geol. 84 101-114. 
Bhattacharya J P and Walker R G 1992 Deltas; In: Facies Models: Responses to sea level change; (eds) Walker R G and James N P, Geolog. Assoc. Canada, pp. 165-193.

Boggs S Jr. 1995 Principles of sedimentology and stratigraphy (2nd edn) Prentice-Hall, Inc. New Jersy; 774 p.

Bose P K and Chakraborty P P 1994 Marine to fluvial transition: Proterozoic Upper Rewa Sandstone, Maihar, India; Sedim. Geol. 89 285-302.

Bose P K, Sarkar S, Chakraborty S, Banerjee S 2001 Overview of the meso- to neoproterozoic evolution of the Vindhyan basin, central India; Sedim. Geol. 141 395-419.

Bouma A H 1962 Sedimentology of some Flysch deposits: A graphic approach to facies interpretation (Amsterdam: Elsevier) 168 p.

Catuneanu O 2002 Sequence stratigraphy of clastic systems: concepts, merits and pitfalls; J. African Earth Sci. 35 $1-43$.

Cattaneo A and Steel R J 2003 Transgressive deposits: a review of their variability; Earth Sci. Rev. 62 187-228.

Chakraborty C 1994 Proterozoic Kaimur Formation, Son valley, India: Facies and sequence in tectonogeographic frame with special bearing on mechanics of clastic sedimentation; Unpubl. Ph.D thesis, Jadavpur University, Kolkata, 175 p.

Chakraborty P P 1996 Facies and sequence development in some late Proterozoic Formations in Son Valley, India with some clues for basin evolution; Unpubl. Ph.D thesis, Jadavpur University, Kolkata, 104 p.

Chakraborty P P, Sarkar S and Bose P K 1998 A viewpoint on intracratonic chenier evolution: clue from a reappraisal of the Proterozoic Ganurgarh Shale, Central India; In: The Indian Precambrian Scientific Publishers; (ed.) B S Paliwal, pp. 61-72.

Chakraborty P P and Sarkar S 2005 Episodic emergence of offshore shale and its implication: Late Proterozoic Rewa Shale, Son Valley, Central India; J. Geol. Soc. India 66 699-712.

Chakraborty T and Chaudhuri A K 1990 Stratigraphy of the late Proterozoic Rewa Group and paleogeography of the Vindhyan basin in central India during Rewa sedimentation; J. Geol. Soc. India 36 383-402.

Collinson J D 1996 Alluvial sediments; In: Sedimentary environments: processes, facies and stratigraphy; 3rd edn, (ed.) Reading H G (Oxford: Blackwell Science) pp. 37-82.

Dickie J R and Hein F J 1995 Conglomeratic fan deltas and submarine fans of the Jurassic Laberge Group, Whitehorse Trough, Yukon Teritorry, Canada: fore-arc sedimentation and unroofing of a volcanic island arc complex; Sedim. Geol. 98 263-292.

Eriksson P G, Condie K C, Tirsgaard H, Mueller W U, Altermann W, Miall A D, Aspler L B, Catuneanu O and Chiarenzelli J R 1998 Precambrian clastic sedimentation systems; Sedim. Geol. 120 5-53.

Fisher R V 1983 Flow transformations in sediment gravity flows; Geology 11 273-274.

Galloway W E 2001 Cenozoic evolution of sediment accumulation in deltaic and shore-zone depositional systems, Northern Gulf of Mexico Basin; Marine and Petroleum Geol. 18 1031-1040.

Hunt D and Tucker M E 1992 Stranded parasequences and the forced regressive wedge systems tract: deposition during base level fall; Sedim. Geol. 81 1-9.

Kidwell S M 1991 Condensed deposits in siliciclastic sequences: expected and observed features; In: Cycles and Events in stratigraphy (eds) Einsele G, Ricken W and Seilacher A (Berlin, Heidelberg: Springer-Verlag) pp. 682-695.

Lowe D R 1982 Sediment gravity flows II: depositional models with special reference to the deposits of high density turbidity currents; J. Sedim. Petrol. 52 279-297.

McPherson J G, Shanmugam G and Moiola R J 1987 Fan deltas and braid deltas: Varieties of coarse-grained deltas; Geol. Soc. Am. Bull. 99 331-340.

Middleton G V and Hampton M A 1973 Sediment gravity flows: Mechanics of flow and deposition; In: Turbidites and deep water sedimentation (eds) Middleton G V and Bouma A H, SEPM pacific section short course; pp. $1-38$.

Pantin H M 1979 Interaction between velocity and effective density in turbidity flow: phase-plane analysis with criteria for autosuspension; Marine Geol. 31 59-99.

Sarkar S, Chakraborty S, Banerjee S and Bose P K 2002 Facies sequence and cryptic imprint of sag tectonics in the late Proterozoic Sirbu Shale, central India; In: Precambrian Sedimentary environments (eds) Altermann W and Cocoran P L (Oxford: Blackwell) 168-183.

Shanmugam G, Poffenberger M and Alava J T 2000 Tide dominated estuarine facies in the Hollin and Napo ("T" and "U") Formations (Cretaceous), Sacha Field, Oriente Basin, Ecuador; Am. Assoc. Petrol. Geol. Bull. 84 652-682.

Siringan F P and Anderson J B 1994 Modern shoreface and innershelf storm deposits off the east Texas coast, Gulf of Mexico; J. Sed. Res. B64 99-110. 